\title{
Sociocultural aspects of health and disease and their pragmatic impact.
}

Oopen acess

${ }^{1}$ Faculdade do Juazeiro do Norte (FJN) - Juazeiro do Norte (CE), Brasil

${ }^{2}$ Centro Universitário Dr Leão Sampaio (UNILEÃO) - Juazeiro do Norte (CE), Brasil

${ }^{3}$ Faculdade de Medicina do ABC (FMABC) - Santo André (SP), Brasil

Corresponding author: maryldeslbo@gmail.com

Manuscript received: October 2017 Manuscript accepted: January 2018 Version of record online: June 2018
Sabrina Alaíde Amorim Alves ${ }^{1}$, Maryldes Lucena Bezerra de Oliveira ${ }^{1,2,3}$

\section{Abstract}

Introduction: Several factors are involved in the health-disease process and important points are related to sociocultural aspects that need to be known and interpreted to understand a more general framework that involves health.

Objective: To analyse the sociocultural aspects related to the health and disease process.

Methods: This is a reflexive review study. Thematic categories were established for the development and discussion of results according to the analysis of Bardin.

Results: Sociocultural aspects influence the health of the population based on creation of work in the field of public health.

Conclusion: Many aspects are involved in the health-disease process. All impact in some way on some context in public health and therefore should be analysed and considered.

Keywords: cultural characteristics, health, disease 


\section{INTRODUCTION}

Social and cultural factors are strongly associated with various life processes of the human being. They exist in political and managing contexts and even in the perspective of health and disease. The disparity of factors leads to the development of different strategies to allow greater equity in health care ${ }^{1}$.

Sociocultural characteristics have found fertile ground in terms of the applications and adaptations necessary in the field of collective health. They are forms of knowledge that aid in the interpretation and questions concerning political anthropology and directed to the area of health ${ }^{2}$.

Social subjects undergo constant changes and interactions that must be considered in order to understand how complex relationships occur. One cannot fail to associate and consider these aspects in the determination of related singular aspects ${ }^{3}$.

These sociocultural aspects are embedded in several health areas, especially those most stigmatized by society, such as Human Immunodeficiency Virus (HIV)

\section{METHODS}

This is a reflexive review study. To search for the studies, the following databases were used: PubMed/ MEDLINE, LILACS and Scientific Electronic Library Scielo.

Thematic categories were developed for the development of results and discussion according to

\section{RESULTS}

From the analysis of the findings, two categories were constructed for the evidence and discussion of the object of study. The two categories are presented below along with an indication of the intricate relationship between the various aspects analyses (Figure 1). infection and mental illness ${ }^{1,2}$. Understanding these factors may lead to better outcomes in relation to health directives and even treatment ${ }^{2}$.

In this context, some social determinants of health (DSS) are included that are related to each other in a very important way in public health and which socially vulnerable populations have a deficit. Some of these factors, such as living conditions, work environment, housing conditions and hygiene should be considered ${ }^{4}$.

Population-wide policies are needed to promote behaviour change through educational programmes, the media, access to healthy food as well as social cohesion. This includes policies that seek to establish support networks and strengthen the organization and participation of people and communities ${ }^{5}$.

Thus, there is a need to reflect on factors that are involved in the social field and that influence, in a significant way, the health and disease process in society. The objective of this study was to analyse aspects related to the health and disease process.

Bardin's analysis. These phases were: 1) pre-analysis: phase of initial analysis and formulation of hypotheses; 2) material exploration: this consists essentially of operations of coding, discount or enumeration, according to previously formulated rules; and 3) treatment of results, inference and interpretation.

Thus, sociocultural aspects have an important influence on conceptual and practical aspects in the health context, so that several factors influence the consolidation of public policies and consequently the public health of different populations.

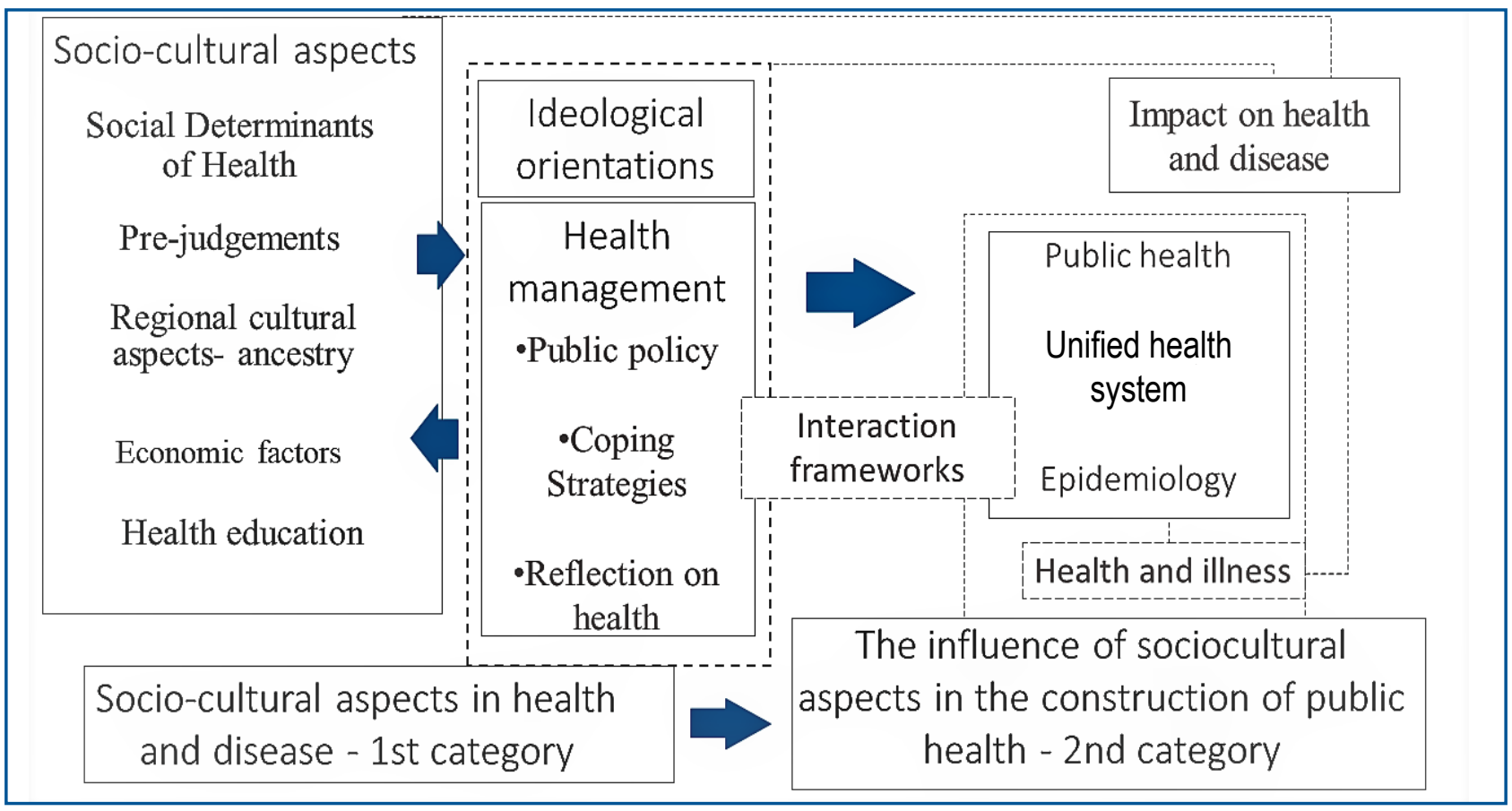

Figure 1: Thematic categories and their contextual relations in health and disease 


\section{DISCUSSION}

\section{Sociocultural aspects of health and disease}

Some sociocultural aspects in society are verified in populations of lower density, such as the indigenous population. Just as in mid 1904, when aspects related to vaccination were debated, so some social representations still need to be considered today, for example in indigenous tribes where a multidisciplinary approach is required to try to incorporate non-cultural concepts and experiences ${ }^{3}$.

In another very common situation, such as in the case of HIV infection, cultural and informational consensus still stigmatizes a particular disease. This dimension mainly concerns conceptions of fatalism and sexuality that transcend the way society views a given situation ${ }^{1}$.

Mental health is also a field that suffers greatly from these cultural aspects. In diseases such as schizophrenia, in which the manifestations of the disease are a little more exacerbated, a prejudgment of conduct is common in social practice and even in the health care that is provided ${ }^{2,6}$.

Policies conceived 40 years ago can be considered as precursors of the so-called 'healthy' public policies in the field of Health Promotion, as they can be considered precursors of more recent movements ${ }^{7}$. From the discussion emerge two strands: one focused on the social and one grounded in biological determination ${ }^{8,9}$.

The term 'social medicine' used in Europe in the second half of the nineteenth century was a forerunner of the idea of health promotion ${ }^{10}$. A new paradigm emerged: the idea that health is produced socially ${ }^{11}$. Thus, health promotion is related to a set of values: democracy, participation, partnership, development, social justice and citizenship $^{12}$.

A healthy environment is one that seeks to express governance commitment to improve health; it presents ways to convene and coordinate local organizations, establishes procedures to circumvent problems, and has mechanisms for closing strategic commitments to implement the follow-up and implementation of those commitments $^{13,14}$.

Not all epidemiology is social, it is differentiated by investigating the determinants of health and disease ${ }^{15,16}$. In this context, it is important to adopt the ecological triad of the agent, host and environment ${ }^{17}$. The social determinants of health are the ethnic, psychosocial, economic, cultural and behavioural factors that influence the occurrence of health problems ${ }^{18}$. Economic and social conditions have an important effect on health and disease and such relations must be submitted to scientific research ${ }^{19,20}$.

The main challenge for studies on the relations between social determinants and health is to define which are the most influential among the more general social, economic and political factors, and the mediations through which these factors affect the health situation of groups and individuals ${ }^{21,22}$.

\section{CONCLUSION}

Several factors and aspects are involved in the health and disease process. These are points that impact in different ways on the practical presentation of health

\section{The influence of sociocultural aspects in the construction of public health}

The so-called cultural integration that guides populations can be the practical origin of several problems present in the field of health ${ }^{23}$. Communication deficiencies and compliance with treatment are some of the most common factors to be found when dealing with mainly cultural conceptions not addressed by strategies such as health education ${ }^{21,24}$.

Problems of cultural origin are more prevalent in the female population. This is a fact mainly verified when it comes to sexuality and other intimate aspects, in which there is a discomfort in addressing such issues, which leads to the expression of feelings becoming limited, which ultimately undermines the whole person approach ${ }^{10,25}$.

Religion is another very important factor in this context. Religion and family ties, in which characteristic social and cultural aspects prevail, aid in the process of coping with certain diseases and more critical situations. In the face of narrower cultures and religions, the adaptation required for the acceptance of change does not occur in a linear way, which harms how the individual enters the field of confrontation ${ }^{5,26,27}$.

These are influences that also have repercussions in chronic diseases, such as diabetes mellitus. In this regard, the subjugation of preventive guidelines for diseases negatively impacts the subjects' health because they do not recognize some determinants as influential in their health ${ }^{28-30}$.

Preventive aspects that become impaired also occur in sexually transmitted diseases, such as HIV. Not only restricted, the search for diagnosis and treatment is hampered by the same cultural conceptions and prior judgment that involves much of human sexuality ${ }^{1,31}$.

Stigmatization in mental health also occurs in a significant way. Non-routine behaviour in society leads to a process of social exclusion that aggravates the way the individual fits him/herself into the social environment ${ }^{32,33}$. It is a fact that this hinders the process of recovery and treatment $\mathrm{t}^{34,35}$.

Some racial and ethical disparities, as well as socioeconomic factors, also influence the contextual balance of variables that are related to the health and disease process in children and adolescents. Differences, for example, in nutritional status may vary according to economic variables, nutrition considered a primary factor in health ${ }^{34}$.

Thus, many aspects relate to the health and disease process. There is a pragmatic identification and orientation about these aspects, since they guide the way society and management behave in the context of health, directly affecting those individuals most affected ${ }^{36,37}$.

in society and that deserve to be studied for a greater organizational delineation of health in a practical context. 
1. Torres López TM, Reynaldos Quinteros C, Lozano González AF, Munguía Cortés JA. Concepciones culturales del VIH/Sida de adolescentes de Bolivia, Chile y México. Rev Saude Publica. 2010;44(5): 8209. DOI: http://dx.doi.org/10.1590/S0034-89102010000500007

2. Mateus MD, Santos JQ, Mari JJ. Popular conceptions of schizophrenia in Cape Verde, Africa. Rev Bras Psiquiatr. 2005;27(2): 101-7. DOI: http://dx.doi.org/10.1590/S1516-44462005000200006

3. Garnelo L. Aspectos socioculturais de vacinação em área indígena. Hist Cienc Saude-Manguinhos. 2011;18(1):175-90. DOI: http://dx.doi.org/10.1590/S0104-59702011000100011

4. Garbois JA, Sodré F, Dalbello-Araujo $M$. Da noção de determinação social à de determinantes sociais da saúde. Saúde Debate. 2017;41(112):63-76. DOI: http://dx.doi.org/10.1590/0103-1104201711206

5. Dagsvold I, Møllersen S, Stordahl V. What can we talk about, in which language, in what way and with whom? Sami patients' experiences of language choice and cultural norms in mental health treatment. Int J Circumpolar Health. 2015;4:26952. DOI: http://dx.doi.org/10.3402/ijch.v74.26952

6. Bonfim ML, Mattos FF, Ferreira EF, Campos AC, Vargas AM. Social determinants of health and periodontal disease in Brazilian adults: a cross-sectional study. BMC Oral Health. 2013;13:22. DOI: http://dx.doi.org/10.1186/1472-6831-13-22

7. Cheney AM, Ostrach B, Marcus R, Frank C, Ball C, Erickson PI. A culture of future planning. Qual Health Res. 2014;24(10) 1451-62. DOI: http://dx.doi.org/10.1177/1049732314548595

8. Sabone MB. The dynamics, dilemmas and complexities of AIDS: The cultural context of Botswana. Issues Ment Health Nurs. 2015;36(2):118-26. DOI: http://dx.doi.org/10.3109/01612840.2014.938208

9. Antunes FP, Costa MCN, Paim JS, Vieira-da-Silva LM, Cruz AA, Natividade M, et al. Desigualdades sociais na distribuição espacial das hospitalizações por doenças respiratórias. Cad Saude Publica. 2013;29(7): 1346-56. DOI: http://dx.doi.org/10.1590/S0102-311X2013000700009

10. Sundaram N, Schaetti C, Merten S, Schindler C, Ali SM, Nyambedha EO, et al. Sociocultural determinants of anticipated oral cholera vaccine acceptance in three African settings: a meta-analytic approach. BMC Public Health. 2016;16:36. DOI: http://dx.doi.org/10.1186/s12889-016-2710-0

11. Duarté-Vélez Y, Bernal G, Bonilla K. Culturally adapted cognitive-behavior therapy: integrating sexual, spiritual, and family identities in an evidence-based treatment of a depressed Latino adolescent. J Clin Psychol. 2010;66(8):895-906. DOI: http://dx.doi.org/10.1002/jclp.20710

12. Rutter SJ, Kiemle G. Exploring the social and interpersonal experiences of South Asian women with a diagnosis of Systemic Lupus Erythematosus. Psychol Health. 2015;30(3):318-35.

DOI: http://dx.doi.org/10.1080/08870446.2014.972397

13. Shenoi SD, Prabhu S. Role of cultural factors in the biopsychosocial model of psychosomatic skin diseases: an Indian perspective. Clin Dermatol. 2013;31(1):62-5. DOI: http://dx.doi.org/10.1016/j.clindermatol.2011.11.008

14. Dowbor TP, Westphal MF. Determinantes sociais da saúde e o Programa Saúde da Família no município de São Paulo. Rev Saude Publica. 2013;47(4):781-90. DOI: http://dx.doi.org/10.1590/S0034-8910.2013047004585

15. Zeilani R, Seymour JE. Muslim women's narratives about bodily change and care during critical illness: a qualitative study. J Nurs Scholarsh. 2012;44(1):99-107. DOI: http://dx.doi.org/10.1111/j.1547-5069.2011.01427.x

16. Humphry J, Jameson LM, Beckham S. Overcoming social and cultural barriers to care for patients with diabetes. West J Med. 1997; 167(3):138-44.

17. Martínez-Hernáez A. Cuando las hormigas corretean por el cerebro: retos y realidades de la psiquiatría cultural. Cad Saude Publica. 2006;22(11):2269-80. DOI: http://dx.doi.org/10.1590/S0102-311X2006001100002

18. Salcedo-Rocha AL, Alba-García JEG, Sevila E. Dominio cultural del autocuidado en diabeticos tipo 2 con y sin control glucémico en México. Rev Saude Publica. 2008;42(2):256- 64. DOI: http://dx.doi.org/10.1590/S0034-89102008000200010

19. Ma Z. When love meets drugs: pharmaceuticalizing ambivalence in post-socialist China. Cult Med Psychiatry. 2012;36(1):51-77. DOI: http://dx.doi.org/10.1007/s11013-012-9247-1

20. Silocchi C, Junges JR. Equipes de atenção primária: dificuldades no cuidado de pessoas com doenças crônicas não transmissíveis. Trab Educ e Saúde. 2017;15(2): 599-615. DOI: http://dx.doi.org/10.1590/1981-7746-sol00056

21. Tjiam AM, Akcan H, Ziylan F, Vukovic E, Loudon SE, Looman CW, et al. Sociocultural and psychological 
determinants in migrants for noncompliance with occlusion therapy for amblyopia. Graefes Arch Clin Exp Ophthalmol. 2011;249(12):1893-9. DOI: http://dx.doi.org/10.1007/s00417-011-1637-5

22. Rosenbaum AJ, Uhl RL, Rankin EA, Mulligan MT. Social and Cultural Barriers: Understanding Musculoskeletal Health Literacy : AOA critical issues. J Bone Jt Surg. 2016; 98(7):607-15. DOI: http://dx.doi.org/10.2106/JBJS.0.00718

23. Ellis HA. Mental Health Disparities in the Older Afro-Caribbean Population Living in the United States: Cultural and Practice Perspectives for Mental Health Professionals. J Psychosoc Nurs Ment Health Serv. 2012;50(9):36-44. DOI: http://dx.doi.org/10.3928/02793695-20120807-03

24. Riquinho DL. A outra face dos determinantes sociais de saúde: subjetividades na construção do cotidiano individual e coletivo em uma comunidade rural. Dissertação (Mestrado) - Universidade Federal do Rio Grande do Sul. Porto Alegre: 2009.

25. Higashi P, Simonetti JP, Carvalhaes MABL, Spiri WC, Parada CMGL. Situações potencialmente geradoras de estresse para enfermeiros segundo condição de acreditação do hospital. Rev Rene. 2013;14(6):1141-8. DOI: http://dx.doi.org/10.15253/rev\%20rene.v14i6.3728

26. Banning M, Hafeez H, Faisal S, Hassan M, Zafar A. The Impact of Culture and Sociological and Psychological Issues on Muslim Patients With Breast Cancer in Pakistan. Cancer Nurs. 2009;32(4):31724. DOI: http://dx.doi.org/10.1097/NCC.0b013e31819b240f

27. Rostain AL. Health Care-Seeking Behaviors of African American ADHD patients and their families: overcoming economic and cultural barriers. J Clin Psychiatry. 2015;76(2):e4.

DOI: http://dx.doi.org/10.4088/JCP.13008tx1c

28. Nicolaisen I. Cultural perceptions, gestational diabetes, and development. Int J Gynecol Obstet. 2009;104(Suppl 1):S8-10. DOI: http://dx.doi.org/10.1016/j.ijgo.2008.11.020

29. Fernandez JCA, Fernandez JCA. Determinantes culturais da saúde: uma abordagem para a promoção de equidade. Saúde Soc. 2014;23(1):167-79. DOI: http://dx.doi.org/10.1590/S0104-12902014000100013

30. Sagbakken M, Frich JC, Bjune GA, Porter JDH. Ethical aspects of directly observed treatment for tuberculosis: a cross-cultural comparison. BMC Med Ethics. 2013;14:25. DOI: https://dx.doi.org/10.1186/1472-6939-14-25

31. Nakimuli-Mpungu E, Wamala K, Okello J, Alderman S, Odokonyero R, Musisi S, et al. Developing a culturally sensitive group support intervention for depression among HIV infected and non-infected Ugandan adults: A qualitative study. J Affect Disord. 2014;163:10-7. DOI: https://dx.doi.org/10.1016/j.jad.2014.03.042

32. Yamamoto T, Kondo K, Aida J, Suzuki K, Misawa J, Nakade M, et al. Social determinants of denture/ bridge use: Japan gerontological evaluation study project cross-sectional study in older Japanese. BMC Oral Health. 2014;14:63. DOI: https://dx.doi.org/10.1186/1472-6831-14-63

33. Costa MGSG, Dimenstein MDB, Leite JF. Condições de vida, gênero e saúde mental entre trabalhadoras rurais assentadas. Estud Psicol. 2014;19(2):145-54. DOI: http://dx.doi.org/10.1590/S1413-294X2014000200007

34. Rossen LM, Talih M. Social determinants of disparities in weight among US children and adolescents. Ann Epidemiol. 2014;24(10):705-13. DOI: http://dx.doi.org/10.1016/j.annepidem.2014.07.010

35. Allen J, Balfour R, Bell R, Marmot M. Social determinants of mental health. Int Rev Psychiatry. 2014;26(4):392-407. DOI: http://dx.doi.org/10.3109/09540261.2014.928270

36. Gölge UH, Kaymaz B, Kömürcü E, Eroğlu M, Göksel F, Nusran G. Consultation of traditional bone setters instead of doctors: Is it a sociocultural and educational or social insurance problem? Trop Doct. 2015;45(2):91-5. DOI: http://dx.doi.org/10.1177/0049475514566531

37. Atukunda EC, Mugyenyi GR, Oloro J, Hughes S. Tackling sexually transmitted infection burden in Ugandan communities living in the United Kingdom: a qualitative analysis of the socio-cultural interpretation of disease and condom use. Afr Health Sci. 2015;15(3): 878-87. DOI: http://dx.doi.org/10.4314/ahs.v15i3.23 


\section{Resumo}

Introdução: Diversos fatores estão envolvidos no processo de saúde e doença e importantes pontos se relacionam a aspectos socioculturais os quais necessitam ser entendidos e interpretados para entendimento de um arcabouço mais geral que envolve a saúde.

Objetivo: Analisar os aspectos socioculturais relacionados ao processo de saúde e doença.

Método: Trata-se de um estudo de revisão reflexiva. Foram construídas categorias temáticas para o desenvolvimento dos resultados e discussão segundo a análise de Bardin.

Resultados: Os aspectos socioculturais influenciam na saúde da população fundamentado na criação de trabalho no campo da saúde pública.

Conclusão: Muitos aspectos estão envolvidos no processo de saúde e doença. Todos impactam de alguma forma em algum contexto na saúde pública e por isso devem ser analisados e considerados.

Palavras-chave: aspectos culturais, saúde, doença.

- The authors (2018), this article is distributed under the terms of the Creative Commons Attribution 4.0 International License (http://creativecommons.org/licenses/by/4.0/), which permits unrestricted use, distribution, and reproduction in any medium, provided you give appropriate credit to the original author(s) and the source, provide a link to the Creative Commons license, and indicate if changes were made. The Creative Commons Public Domain Dedication waiver (http://creativecommons.org/publicdomain/zero/1.0/) applies to the data made available in this article, unless otherwise stated. 